Fastabiq: Jurnal Studi Islam

ISSN 2723-0228

Volume 1 Nomor 1 Juni 2020

Halaman 42-60

\title{
MAJLIS TAKLIM DAN AKTUALISASI VISI ISLAM TRANSFORMATIF
}

\author{
Firman Nugraha \\ Balai Pendidikan dan Pelatihan Keagamaan Bandung \\ Jl. Soekarno Hatta No.716 Bandung \\ firmanugraha@kemenag.go.id
}

\begin{abstract}
The purpose of writing this article is to describe the actualization of the transformative vision of Islam in the religious economic movement. This transformative vision is the theological spirit contained in the Koran. A spirit that manifests in the da'wah movement. Da'wah actions that answer the problems of the Ummah rather than just verbal activities. Da'wah action can be started from activities in majlis taklim. Majlis taklim is a necessity as a laboratory for social change in Muslim circles. The extraordinary existence of majlis taklim can be transformed into social capital as a formulation of transformative vision through reading the context of the challenges of Muslims while referring to the Qur'anic doctrine. Through the spirit of the theology of change, da'i has become not only a religious social elite class but also a person who has a vision of change in society with his da'wah movement.
\end{abstract}

Keywords: da'wah, social change, transformative theology

\section{Abstrak}

Artikel ini bermaksud untuk mendeskripsikan aktualisasi visi transformatif Islam dalam gerakan ekonomi keagamaan. Visi transformatif ini merupakan semangat teologis yang terkandung dalam al Quran. Suatu semangat yang mewujud dalam gerakan dakwah. Dakwah aksi bertujuan untuk lebih menjawab persoalan ummat daripada sekedar kegiatan verbal. Dakwah aksi ini, salah satunya, dapat dimulai dari kegiatan di majlis taklim. Metode yang digunakan adalah studi eksplorasi yang dianalisis dengan pendekatan kualitatif. Hasil penelitian mengungkapkan bahwa keberadaan dan peran majlis taklim merupakan keniscayaan sebagai laboratorium perubahan sosial di lingkungan masyarakat muslim. Eksistensi majlis taklim yang luar biasa banyak dapat diubah menjadi modal sosial sebagai wadah perumusan visi transformatif melalui pembacaan konteks tantangan umat Islam seraya merujuk kepada doktrin al Quran. Melalui semangat teologi perubahan, da'i telah menjadi bukan hanya kelas elit sosial keagamaan melainkan juga orang yang memiliki visi perubahan di masyarakat dengan gerakan dakwahnya.

Kata kunci: Dakwah Aksi, Majlis Taklim, Teologi Perubahan,

\section{PENDAHULUAN}

Islam, sejak awal, hadir di muka bumi ini dengan visi transformatif. Dengan kata lain, bukan sekadar menghendaki terjadinya perubahan aqidah dari jahiliyah kepada Islam, tetapi juga melakukan perubahan sosial dari masyarakat yang tidak adil, zalim, dan sewenang-wenang menjadi masyarakat yang adil, damai, dan menghargai perbedaan kelas sosial. Karena itulah dakwah Islam yang dilakukan pertama kali memiliki visi yang jelas tentang landasan transformatif. Yakni, sikap teologis yang mengharuskan setiap kaum beragama untuk membawa dan membumikan ide-ide agama dalam pergulatan hidup secara kolektif demi menegakkan tatanan sosial yang adil.

Islam transformatif meliputi upaya-upaya penafsiran terhadap wahyu yang memihak kepada orang-orang tersingkir, tertindas dari mobilitas sosial, atau bahkan tersubordinasi. ${ }^{1}$ Namun demikian, ajaran Islam sekarang ini tampaknya telah kehilangan makna substansialnya untuk menjawab problem-problem kemanusiaan. Hal ini seperti terindikasi dari keberagamaan masyarakat yang pada umumnya belum bersifat transformatif. Agama hanya dinilai sebagai sesuatu yang transenden atau di 


\section{Fastabiq: Jurnal Studi Islam}

ISSN 2723-0228

Volume 1 Nomor 1 Juni 2020

luar realitas sosial. Dari gambaran tersebut, jangan heran bila acap kali dapat ditemui sketsa atau potret keberagamaan yang kontradiktif, timpang, paradoks antara tingkat kesalehan individu dengan kesalehan sosial. $^{2}$

Visi transformatif mendorong pada kepedulian terhadap nasib sesama yang akan melahirkan aksi solidaritas dengan tujuan mempertalikan mitra insani atas dasar kesadaran iman bahwa sejarah suatu kaum hanya akan diubah oleh Tuhan jika ada kehendak dan upaya dari semua anggota kaum itu sendiri. Transformasi merupakan jalan yang paling manusiawi untuk mengubah sejarah kehidupan umat manusia. Sebab, dalam proses ini yang berlaku adalah pendampingan dan bukan pengarahan apalagi pemaksaan. Transformasi pada dasarnya juga adalah gerakan kultural yang didasarkan pada liberalisasi, humanisasi, dan transendensi yang bersifat profetik. Suatu pengubahan sejarah kehidupan masyarakat oleh masyarakat itu sendiri ke arah yang lebih partisipatif, terbuka dan emansipatoris $^{3}$

Terdapat dua prinsip dalam tata kerja visi transformatif. ${ }^{4}$ Pertama, prinsip nahyu 'an al-munkar (mencegah kemungkaran). Prinsip ini menegaskan bahwa agama sangat membenci semua bentuk rekayasa sosial yang dapat mengikis dan menelanjangi harkat dan martabat manusia yang mengarah kepada terjadinya dehumanisasi. Jadi, prinsip ini sekaligus menegaskan bahwa kefakiran beserta segala jenis fragmentasi sosialnya merupakan kekufuran yang harus diangkat derajatnya yang lebih tinggi.

Kedua, prinsip amr bi al-ma'ruf (memerintah pada kebajikan). Prinsip ini berawal dan sebuah keyakinan bahwa setiap manusia dilahirkan dalam lokus sosial yang sederajat dan terhormat. Meskipun demikian, bila ternyata manusia dilahirkan dalam kondisi kepayahan yang memprihatinkan, semua itu harus diubah. Nilai-nilai universal kemanusiaan (juga agama), seperti keadilan sosial, kemakmuran dan kebebasan, mesti diwujudkan secara nyata melalui redistribusi sosial sebagai bagian yang tak bisa dipisahkan dari komitmen suci keimanan dan tauhid. Artinya, terciptanya tatanan masyarakat yang berkeadilan sosial merupakan suatu kemutlakan, kemestian dan sebuah keberagamaan yang benar.

Sementara itu, dakwah pada dasarnya merupakan salah satu cara untuk melakukan perubahan sosial. Perilaku masyarakat yang melanggar norma dan etika yang berlaku dalam kehidupan bermasyarakat harus "diluruskan" agar dampak buruknya tidak menyebar dan menjadi "penyakit" kolektif. Melalui gerakan dakwah, masyarakat seyogianya dibimbing dan diarahkan kepada hal-hal positif yang tidak hanya bermanfaat bagi dirinya, tetapi juga bermanfaat bagi orang lain.

Realitas sosial memang selalu membutuhkan tuntunan spiritual agar sejalan dengan petunjuk Tuhan. Kaum Muslim, sejak Nabi Muhammad diutus untuk menyampaikan risalah Islam hingga zaman modern ini, telah dijadikan sebagai umat terbaik karena peran mereka dalam perubahan sosial. ${ }^{5}$ Posisi "umat terbaik" memiliki konsekuensi aktif melakukan perbaikan-perbaikan atas tatanan sosial yang kurang atau bahkan belum baik. Jadi tugas dakwah itu sangat melekat kuat pada setiap individu (fardlu 'ain) yang merasa, atau dipandang, baik.

Dakwah Islam, bila dilihat dari sisi prosesnya, merupakan usaha transformasi sosial yang bergerak di antara doktrin dan realitas masyarakat yang menjadi objek utamanya. Untuk mendukung 


\section{Fastabiq: Jurnal Studi Islam}

ISSN 2723-0228

Volume 1 Nomor 1 Juni 2020

hal tersebut, dalam menyampaikan materi dakwah, perlu memperhatikan aspek-aspek kultural. ${ }^{6}$ Lebih lanjut dijelaskan bahwa kegiatan dakwah merupakan aktualisasi keimanan yang dimanifestasikan dalam suatu kegiatan manusia untuk melakukan rekayasa sosial melalui usaha mempengaruhi cara merasa, berpikir, bersikap dan berperilaku sesuai dengan tuntutan sosial dan norma ajaran.

Dakwah dalam bentuk rekayasa sosial (taghyir ijtima'i) adalah cara untuk mengubah tatanan kondisi masyarakat yang menyimpang, salah ke arah yang benar dan terarah ${ }^{7}$. Selain itu, ada ungkapan lain yang senada dengan rekayasa sosial yaitu: Ikhraj in al-zhhulumat ila al-nur (membebaskan manusia dari kegelapan menuju terang benderang); al-islah (reformasi); al-dakwah ila Allah (menyeru ke jalan Allah); al-amru bi al ma'ruf wa al-nahyu an al-munkar (memerintahkan kebaikan dan mencegah kemunkaran); dan al-inzdar (peringatan) ${ }^{8}$. Dalam tinjauan sejarah, diketahui bahwa rasulullah merupakan pelaku rekayasa sosial (agent of social change) dan agen pembangunan (agent of development).

Kegiatan dakwah dalam konteks kegiatan rekayasa sosial memerlukan adanya tindakan sosial. Tindakan sosial merupakan perbuatan manusia yang dilakukan dengan maksud dan tujuan tertentu. Tindakan merupakan hasil proses belajar. Umumnya setiap manusia akan bertindak berdasarkan akal. la akan menyeleksi berbagai alternatif untuk mencapai tujuan seoptimal mungkin. Dengan demikian, tindakan mempunyai hubungan yang erat dengan kehidupan bermasyarakat. Dalam kehidupan bermasyarakat, seseorang melakukan aktivitas hubungan dengan orang lain melalui tindakan ${ }^{9}$.

Selanjutnya, dalam melakukan tindakan sosial tersebut akan terjadi interaksi sosial, dalam pengertian bahwa hubungan dinamis antara orang dengan orang, kelompok dengan kelompok, maupun antara orang dengan kelompok. Interaksi terjadi apabila individu bertindak sedemikian rupa sehingga menimbulkan reaksi dari individu lainnya. Interaksi sosial merupakan hubungan yang tertata dalam bentuk tindakan yang didasarkan pada nilai-nilai dan norma sosial yang berlaku dalam masyarakat ${ }^{10}$.

Interaksi sosial dalam praktiknya dibedakan menjadi imitasi, sugesti, indentifikasi, dan simpati. Imitasi merupakan bentuk duplikasi dari suatu keadaan oleh keadaan lainnya yang memberikan peluang agar tersebarnya suatu gagasan atau suatu keadaan dalam ruang yang lebih luas. Perkembangan teknologi dan perubahan sosial di tingkat mikro dengan proyek imitasi cenderung dapat mempercepat penyebarannya. Hal penting yang perlu diwaspadai adalah imitasi memberikan kemungkinan bukan hanya potensi positif yang terduplikasi melainkan, pada saat yang sama, juga dengan potensi negatifnya.

Interaksi sosial dalam bentuk sugesti yaitu adanya keterpengaruhan suatu objek oleh objek lainnya. Model hubungan sugesti ini salahsatu pihak berada dalam domain yang lebih kuat (superior) bagi pihak lainnya yang tersugesti. Interaksi model ini berimbas pada kemungkinan pewarnaan dinamika sosial yang relatif seragam karena mengikuti pola yang yang sudah ada.

Identifikasi dan simpati menjadi pola interaksi sosial yang dapat dianggap setara hubungannya. Dua belah pihak yang berkomunikasi, masing-masing memberikan jarak untuk memahami bagaimana keadaan mitranya. Sikap yang terbuka namun bijak layak untuk diterapkan. 


\section{Fastabiq: Jurnal Studi Islam}

ISSN 2723-0228

Volume 1 Nomor 1 Juni 2020

Mengidentifikasi hal-hal yang dapat dijadikan jembatan penghubung disertai sikap yang simpatik untuk dapat membuka jalinan komunikasi yang baik menjadi pendorong yang penting. Sikap ini memberikan kontribusi positif untuk membangun keadaban publik.

Syarat terjadinya interaksi sosial adalah adanya kontak dan komunikasi. Kontak sosial merupakan aksi individu atau kelompok yang mempunyai maksud dari pelakunya dan ditangkap oleh individu atau kelompok lain. Kontak dapat dibedakan menjadi kontak langsung dan kontak tidak langsung. Kontak langsung dapat terjadi dalam tiga bentuk, yaitu antara individu dengan individu, individu dengan kelompok, dan antara kelompok dengan kelompok. Selain itu kontak dapat bersifat positif dan negatif.

Agar Islam bisa memerankan fungsinya secara dialektis konstruktif, sebagaimana telah diulas di atas, maka perlu dikembangkan program reinterpretasi pesan-pesan agama. Dalil-dalil normatif yang ada dalam Alquran dan Hadits harus diturunkan dalam bentuk teori-teori sosial yang dapat diaplikasikan. Atau, lebih tepatnya harus dikontekstualisasikan agar berfungsi historis, kekiniaan, dan kedisinian.

Kaitannya dengan hal tersebut, para ulama atau para pemuka agama sangat dibutuhkan dalam melakukan reinterpretasi agama. Ulama diharapkan berperan langsung dalam melakukan pencerahan kepada masyarakat melalui upaya-upaya re-interpretasi agama, sehingga pesan-pesan yang dibawa agama menjadi fungsional serta ajaran keadilan, toleransi dan cinta kasih yang terkandung dalam agama menjadi implementatif dan integratif dalam kehidupan bermasyarakat dan berbangsa.

Artikel ini, berupaya untuk mengeksplorasi relasi antara pemahaman teologis dengan visi transformatif dalam kaitannya dengan kerangka aksi menuju perubahan sosial umat Islam yang dibidani oleh majlis taklim.

\section{METODE PENELITIAN}

Studi dilakukan dengan menganalisis interaksi sosial yang berlaku dalam kelompok muslim di perdesaan khususnya yang terikat solidaritas majlis taklim. Fokus penelitian berlangsung pada aktivitas Majlis Taklim al Falah Desa Arjasari, Kecamatan Arjasari Kabupaten Bandung. Data diperoleh melalui pengamatan partisipatif dan wawancara dengan narasumber. Semua informasi yang diperoleh kemudian dianalisis dalam upaya menemukan cara dan model aktualisasi visi transformasi Islam dalam lingkungan perdesaan.

\section{PEMBAHASAN}

\section{Majlis Taklim dan Refresentasi Kelompok Keagamaan}

Proses rekayasa sosial niscaya memerlukan wadah yang tepat. Kesadaran kolektif ini, bagi umat Islam menemukan spirit yang relevan dengan dimensi teologisnya. ${ }^{11}$ Lain dari itu, kesadaran ini juga memiliki saluran yang memungkinkan dapat menjadi penampung gerakan. Pranata penting yang dimiliki umat Islam adalah masjid ${ }^{12}$ dan majlis taklim ${ }^{13}$. Majlis taklim, sebagai wadah perkumpulan 


\section{Fastabiq: Jurnal Studi Islam}

ISSN 2723-0228

Volume 1 Nomor 1 Juni 2020

untuk aktifitas keagamaan, keberadaannya tidak dapat diabaikan. ${ }^{14}$ la hadir dalam setiap komunitas muslim, baik perdesaan maupun perkotaan. Keberadaanya dapat menjadi reprensentasi aktifitas keagamaan kelompok organisasi kemasyarakatan Islam maupun independen atas prakarsa tokoh. ${ }^{15}$. Majlis taklim merupakan wadah integratif dalam dialog masyarakat, baik di perkotaan maupun perdesaan. Melihat keberadaannya yang strategis tersebut, idealnya model pemberdayaan masyarakat Islam dapat dimulai dari majlis taklim. ${ }^{16}$

Keberadaan majlis taklim tampaknya sama tuanya dengan pergerakan awal dakwah Islam di Nusantara. Meski memiliki nama yang berbeda namun kegiatannya relatif sama yakni sebagai tempat sekumpulan umat Islam untuk melakukan kegiatan pembelajaran melalui tokoh atau pihak yang dianggap mengerti mengenai agama (Islam). Jika sebelumnya kegiatan ini merupakan hal yang umum dilakukan tanpa melihat perbedaan gender, maka kini tampaknya telah terjadi penyempitan peristilahan. Majlis taklim kini lebih merujuk pada aktifitas keagamaan kaum perempuan. ${ }^{17}$ Meskipun juga kini bukan berarti kaum pria tidak memiliki aktifitas serupa, namun jarang sekali disebut majlis taklim.

Perkembangan majlis taklim tampak memiliki momentum yang baik pasca runtuhnya orde baru. Pada masa orde baru berkuasa keberadaan majlis taklim dimanfaatkan sebagai bagian dari kontrol pemerintah terhadap aktifitas keagamaan umat Islam dengan tampak [seakan] menyokongnya namun intervensinya sangat kentara seperti pemberian nama al hidayah dan simbol penyeragaman busana anggota atau jemaah majlis taklim. Namun demikian, bukan berarti semua majlis taklim menjadi bagian dari gerakan orde baru, karena ia lebih menjadi pihak yang mencoba menyelami gerakan umat Islam dewasa itu. ${ }^{18}$

Di era reformasi, keberadaan majlis taklim-pun mengalami pertumbuhan dan perkembangan kegiatan yang lebih luas. Perkembangan majlis taklim era reformasi ini mengarah kepada identifikasi baru umat Islam dan refresentasinya yang berbeda antara perkotaan dengan perdesaan. ${ }^{19}$ Di kota, mereka menjadi lebih dinamis yang terbentuk akibat konsesi perubahan sosial dan politik yang terjadi, sementara di perdesaan masih menunjukkan keguyuban dan menjadi inspirator terhadap perubahan sosial di lingkungannya. ${ }^{20}$

\section{Teologi Masa Kini dari Teks ke Gerakan Sosial Keagamaan}

Teologi sering dibaca sebagai aktivitas pemikiran yang transenden, sakral dan berada dalam dimensi batiniyah. Namun demikian, kini teologi mendapat tantangan praksis bagaimana ia dapat menjawab pelbagai persoalan kemanusiaan yang realistis. Dalam konteks ini teologi dimaknai sebagai suatu wacana dengan apa orang beragama, mengembangkan dan mengekspresikan inti keyakinan sebagaimana yang mereka anut ${ }^{21}$. Pemahaman teologi seperti ini menunjukkan bagaimana teologi dituntut untuk lebih fungsional agar mampu merespon dinamika sosial umat manusia.

Islam sebagai agama yang membebaskan dengan semangat teologi perubahan semestinya mampu menjawab problem-problem kemanusiaan. Problem-problem seperti ketidakadilan, penindasan, kewenang-wenangan, dan kemiskinan yang terjadi di tengah-tengah masyarakat. Sehingga Islam tidak kehilangan orientasi horisontalnya dalam menjaga hubungan dengan sesama 


\section{Fastabiq: Jurnal Studi Islam}

ISSN 2723-0228

Volume 1 Nomor 1 Juni 2020

manusia. Islam yang hanya memiliki orientasi vertikal merupakan karakter Islam yang ekslusif dan tidak memiliki semangat perubahan. Padahal, sejak awal, Islam yang didakwahkan memiliki orientasi kemanusiaan yang sangat kuat agar terjadi keseimbangan sosial dalam masyarakat.

Berdasarkan visi teologi transformatif ini umat Islam seharusnya mengerti bahwa mereka itu dilahirkan untuk maju ke garis depan dan memegang kendali kepemimpinan, karena mereka adalah umat yang terbaik. Allah menghendaki supaya kepemimpinan di muka bumi ini untuk kebaikan, bukan untuk keburukan ${ }^{22}$.

Umat Islam menempati posisi khairu ummah (sebaik-baik umat) adalah karena tindakan positifnya untuk memelihara kehidupan manusia dari kemunkaran dan menegakkannya di atas yang makruf disertai dengan iman untuk menentukan batas-batas mana yang makruf dan mana yang munkar itu. Kegiatan itu harus disertai dengan iman kepada Allah, untuk menjadi timbangan terhadap tata nilai dan untuk mengetahui dengan benar mengenai yang makruf dan yang munkar ${ }^{23}$.

Atas kesadaran bahwa problem umat manusia yang dinamis, maka sejatinya kegiatan Amar ma'ruf nahi munkar merupakan proyek jangka panjang kaum Muslim, karena kehidupan dunia ini tak akan bebas dari kemunkaran serta manusia pun tak akan sempurna melakukan kebajikan. Selama dunia ini berputar, maka selama itu pula kemunkaran berlangsung dan manusia tak akan pernah sempurna berbuat kebaikan. Diutusnya para nabi dan rasul yang misi dakwahnya mengajak kepada kebaikan dan mencegah kemunkaran membuktikan bahwa kemunkaran akan terus menyelimuti perilaku masyarakat dan baiknya perilaku masyarakat senantiasa memerlukan peringatan dan pembinaan.

Teologi perubahan dibangun berdasarkan pada jejak-jejak Rasulullah dalam melakukan aktivitas dakwah dan basis doktrinal yang terdapat dalam Alquran. Misi transformasi dakwah nabi memiliki argumentasi teologis yang kuat bahwa kerja dakwah ini bukan hanya pemikiran rasional semata, melainkan juga menjadi perhatian dalam Alquran dan Sunnah Nabi.

Bercermin dari dakwah Nabi Muhammad Saw di Mekah yang sudah sadar bahwa misi dakwah yang utama selain persoalan akidah juga bagaimana menjawab problem-problem sosial yang terkait dengan masalah kemiskinan, kefakiran, ketidakadilan ekonomi, rendahnya moralitas dan kemanusiaan, kezaliman, dan ketidakdilan yang dilakukan masyarakat Arab. Problem konkret di masyarakat Arab ketika itu menghendaki seorang juru dakwah yang tidak hanya melakukan perubahan kepercayaan dan keimanan, tetapi yang secara konkret mampu membangun kesadaran baru untuk mengatasi problem ketidakadilan sosial, ekonomi, dan politik, yang dihadapi masyarakat Arab.

Dengan demikian, dakwah Nabi Muhammad bukan hanya penyebaran akidah Islam, tetapi juga untuk mengubah struktur masyarakat yang sudah bobrok. Nabi Muhammad berbeda dengan pendakwah lain. Dia tidak berminat hanya mengajarkan moralitas individu di dalam tatanan sosial yang bobrok. Persoalan yang dia hadapi bukanlah moralitas bawaan individu semata; baginya persoalan moral juga merupakan persoalan sosial, dan dengan demikian moralitas barunya hanya bisa dibangun dengan jalan mengubah struktur sosial yang sudah usang ${ }^{24}$. 


\section{Fastabiq: Jurnal Studi Islam}

ISSN 2723-0228

Volume 1 Nomor 1 Juni 2020

Karena itulah, pembacaan terhadap perjalanan sejarah nabi menghasilkan tiga jenis transformasi ${ }^{25}$ (Hilmy 2008). Pertama, transformasi sosiokultural. Sebelum Nabi Muhammad diutus Allah, struktur masyarakat Arab dikenal amat feodal dan paternal yang selalu melahirkan fenomena penindasan. Secara garis besar, mereka terbagi ke dalam dua kelas yang saling bertentangan; kelas terhormat yang menindas (syarif/ the oppressor) dan kelas budak dan orang miskin yang tertindas (mustadh'afin/the oppressed).

Islam turun membawa pesan egalitarianisme di semua bidang kehidupan. Islam yang dibawa Nabi Muhammad tidak lagi mengenal polarisasi miskin-kaya, lemah-kuat, penindas-tertindas, penguasa dikuasai, dan seterusnya. Tidak ada lagi perbedaan manusia berdasar warna kulit, ras, suku, atau bangsa. Mereka dibedakan bukan oleh hal-hal yang bersifat fisik, tetapi nilai keimanan dan ketakwaannya $^{26}$ (QS. 48:13). Konsep transformasi yang dicetuskan 14 abad lalu itu amat revolusioner, bukan saja bagi masyarakat Arab, tetapi umat manusia secara keseluruhan yang cenderung bertindak rasis dan diskriminatif terhadap sesama.

Kedua, keadilan ekonomi. Sejak diturunkan, al-Quran amat menekankan pemerataan dan keadilan untuk semua, bukan untuk sekelompok orang. la amat menentang penumpukan dan perputaran harta pada orang-orang kaya saja ${ }^{27}$ (QS. 59:7), sementara orang miskin selalu tertindas secara struktural dan sistemik. Untuk keperluan ini, Alquran juga menganjurkan orang berpunya untuk menafkahkan sebagian hartanya kepada yang tak punya ${ }^{28}$ (QS 2:219). Bagi mereka yang tertindas, Allah tidak saja telah menganjurkan untuk melawan segala bentuk penindasan dan penjajahan, namun juga menjanjikan mereka kernenangan ${ }^{29}$ (QS. 28:5). Hari ini, tampaknya keadilan masih menjadi barang luxurious, terlebih bagi kalangan lemah- tertindas. Keadilan kesannya hanya milik kaum berpunya. Hal ini amat dirasakan manakala melihat kebijakan pembangunan yang disinyalir cenderung merugikan wong cilik.

Ketiga, sikap terhadap agama lain. Keterbukaan, toleransi, dan respek pada agama lain merupakan elemen liberatif lain dalam Islam. Alquran telah membuat diktum secara tegas, tidak ada pemaksaan dalam beragama $^{30}$ (QS 2:256), bagimu agamamu, bagiku agamaku ${ }^{31}$ (QS. 109:6), dan Alquran telah mengajarkan penghorrnatan kepada semua Nabi yang diturunkan Allah ke dunia ${ }^{32}$ (QS. 4:150-151). Toleransi yang kuat dalam sejarah Islam di Madinah telah melahirkan sikap-sikap yang moderat dan pro perdamaian, sehingga terjadi masyarakat pluralistik yang damai.

Selain berangkat dari akar historis tersebut di atas, pembacaan atas wahyu (Alquran) dengan pendekatan transformatif juga menjadi titik keberangkatan yang penting menuju teologi perubahan. Tafsir transformatif menekankan pada dua pokok gagasan ${ }^{33}$ (Abdurahman 2003). Pertama, dari aspek proses bermula dari pembacaan sosial dalam rangka menemukan konstruk yang bisa menggambarkan persekutuan sosial hegemonis. Pembacaan ini menurutnya merupakan analisis sosial untuk memahami bagaimana proses penyingkiran kaum proletar (mustadh'afin) dari panggung dinamika sosial.

Tahap pertama ini untuk mendefinisikan siapa yang tertindas dan siapa yang menindas. Siapa yang yang menjadi korban kemunkaran sosial dan siapa yang menjadi pelaku kemunkaran sosial. Konstruksi ini penting, sebab dengannya dapat mengajukan sebuah program aksi nyata melalui 


\section{Fastabiq: Jurnal Studi Islam}

ISSN 2723-0228

Volume 1 Nomor 1 Juni 2020

wadah-wadah sosial (keagamaan) yang tersedia agar tidak hanya terhenti sebagai bentuk festival dalam beragama an-sich melainkan agama dapat tampil seperti semangatnya yang dibawakan Nabi Muhammad untuk menjadi pembela dan mewujudkan tatanan sosial yang berkeadilan.

Kedua, dengan pendekatan tafsir transformatif ini ayat-ayat Alquran menjadi lebih kontekstual dan aktual karena dibaca dalam proses sosial. Alquran bukan hanya menjadi bacaan dogmatis dan teologis yang memberikan berkah di kemudian hari. Konsep Hudan (petunjuk) bukan hanya ada dalam ruang teologis yang berjarak dengan kehidupan sosial melainkan ia menjadi dasar dalam berkehidupan sosial yang sesungguhnya.

Berangkat dari gagasan ini, maka sebuah gagasan transformatif akan melahirkan model dakwah yang aktual dan implementatif. Dakwah bukan lagi hanya meriah dalam panggung-panggung dan mimbar-mimbar ceramah dengan serangkaian retorika verbalistis. Melainkan ia menjadi aksi nyata yang (mungkin) sepi dari retorika verbal namun kaya dengan amal.

Aksi-aksi pemberantasan kemunkaran bukan lagi dengan tindakan 'pemberantasan' yang terkesan brutal dan tidak elegan. Aksi ini lebih kepada bentuk advokasi yang riil lengkap dengan program yang berkesinambungan, namun dalam bayangan spirit teologis yang beretika ketauhidan.

Dakwah model ini-pun sebagai produk dari tafsir transformatif bukan menjadi monopoli kaum elit agama (ulama) melainkan mejadi proyek bersama ${ }^{34}$ (Zada 2006). Sehingga, pemetaan da'i dan mad'u menjadi solid, da'i yang sekaligus mad'u dan juga sebaliknya. Wadah-wadah (pranata sosial keagamaan) yang tersedia semisal, masjid, majlis taklim, pesantren dan atau lembaga lainnya menjadi wadah yang hidup bukan lagi hanya bergulat dalam dimensi transmisi wacana, melainkan menjadi wadah aksi dalam mewujudkan tatanan kehidupan sosial Islam yang sesungguhnya.

3. Gerakan Sosial Ekonomi Keagamaan sebagai aktualisasi teologi transformasi di Majlis Taklim

Arjasari sebagai sebuah wilayah di selatan Kabupaten Bandung, khas dengan dataran tingginya. Secara geografis, Kecamatan Arjasari terletak pada $107^{\circ}, 30^{\prime}-107^{\circ}, 40^{\prime}$ Bujur Timur dan $7^{\circ}, 30^{\prime}-7^{\circ}, 80^{\prime}$ Lintang Selatan. ${ }^{35}$ Sedangkan berdasarkan topografinya seperti halnya wilayah kabupetan Bandung yang berupa pegunungan, sebagian besar wilayah di Kecamatan Arjasari merupakan daerah dataran dan Lereng/Punggung bukit dengan ketinggian di atas permukaan laut bervariasi dari $600 \mathrm{~m}$ sampai $950 \mathrm{~m} \cdot{ }^{36}$ Kontur geografis demikian membawa implikasi ekonomi pada keluarga yang menjadi penduduk di wilayah tersebut berada pada sektor pertanian. ${ }^{37}$ Berdasarkan data Badan Pusat Statistik diketahui bahwa komoditas unggulan dari Arjasari merupakan hasil hutan produktif beruba kopi dan cengkeh. ${ }^{38}$

Arjasari memang kental dengan nuansa pertanian, namun demikian juga terkonfirmasi bahwa telah terjadi pergeseran penguasaan lahan. Para pemilik lahan bukan lagi warga setempat karena sudah menjadi milik para pengusaha atau pemodal yang berada di luar wilayah. Dengan demikian, lahan yang dikuasai petani setempat semakin terbatas. ${ }^{39}$ Mengingat penguasaan lahan tani sangat terbatas dengan adanya industiralisasi, demikian pula pada penduduk di Arjasari. Mereka dominan sebagai penggarap lahan dengan status buruh tani lahan kering. ${ }^{40}$ Lahan yang mereka garap adalah 


\section{Fastabiq: Jurnal Studi Islam}

ISSN 2723-0228

Volume 1 Nomor 1 Juni 2020

milik Sanggar Penelitian dan Latihan Pengembangan Pertanian (SPLPP) Fakultas Pertanian Universitas Padjajaran (Faperta Unpad). ${ }^{41}$

Sebagai wilayah yang berada di wilayah Sunda dan sekaligus dengan angka pemelukan Islam yang signifikan, maka Arajsari tidak lepas dari dua pengaruh kebudayaan tersebut, Sunda dan Islam. ${ }^{42}$ Sebagai wilayah yang hampir 100 persen berpenduduk mulsim, ${ }^{43}$ Di kampung Arjasari tepatnya di RW 06 Desa Arjasari Kecamatan Arjasari mereka penggarap lahan ini memiliki kegiatan keagamaan yang rutin di Majlis Ta'lim Al Falah. ${ }^{44}$

Kehidupan di sektor pertanian dengan pergulatan di sektor ekonomi subsistensi tidaklah menjadikan mereka harus menjauh dari kehidupan yang relijius. Adanya Majlis Taklim al Falah menjadi bukti kuat bahwa keguyuban dalam keagamaan sebagai karakteristik masyarakat perdesaan masih melekat, dan Majlis Taklim al Falah menjadi salahsatu wadah berkumpul kaum ibu untuk dimensi relijius tersebut. Majlis Taklim al Falah merupakan salahsatu dari sekian banyak majlis taklim di Arjasari. Di Arjasari, setiap lingkungan RW (Rukun Warga) dapat dikatakan memiliki majelis taklim. Pada umumnya terikat dengan lingkungan pusat keagamaan seperti pesantren dan masjid. Meskipun jumlah umat Islam adalah mayoritas namun keberadaan pesantren sangatlah sedikit. Pesantren inipun menampilkan corak pesantren tradisional, yang berada di Desa Rancakole. Namun demikian seperti pada umumnya keberadaan majelis taklim lebih merupakan prakarsa warga, dan bersifat swadaya, ${ }^{45}$ maka jumlah majelis taklim dapat lebih banyak daripada keberadaan lembaga Islam lainnya.

Majelis taklim, dari segi istilah memang menampilkan khas kekotaan. Di perdesaan kegiatan pengajian kaum ibu di masa lalu sering disebut dengan madrasah. Hal ini merujuk kepada kegiatan yang sama yaitu pengajian dengan aktifitas mendengarkan ceramah keagamaan dari kiai atau ustadz. Namun seiring menguatnya semangat keberagamaan di perkotaan terutama melalui aktifitas-aktifitas pengajian seperti itu, majelis taklim menjadi lebih populer termasuk di perdesaan.

Majelis taklim, memang lebih umum kesan maknanya daripada madrasah. Hal ini mengingat aktifitas pengajian yang masih jarang menggunakan standar kurikulum. Meskipun menggunakan konsep taklim (ta'lim, arab) ${ }^{46}$ tetapi tidak selalu berarti kegiatannya benar-benar mengkaji bidang tertentu. Sama halnya dengan penggunaan istilah pangaosan atau pengajian. Kondisi jamaah pada umumnya pasif hanya sebagai mitra pendengar dari nara sumber (mu'alim). Narasumber atau mu'alim ini lebih memperlihatkan peranya sebagai mubaligh daripada mu'alim dalam pengertian asalnya. Mu'alim atau orang yang 'alim (berilmu) lebih cenderung dalam penyampaian narasi keagamaannya menggunakan sumber tertentu secara khusus, misalnya mengkaji kitab fiqih atau tafsir. Sementara praktiknya sebagai mubaligh yang lebih dominan ceramah.

Keberadaan majelis taklim di perdesaan dan di perkotaan, meskipun memiliki spirit yang sama yaitu dalam kerangka dakwah, namun menurut Kuntowijoyo berbeda. ${ }^{47}$ Majelis taklim hadir sebagai reaksi atas urbanisasi yang meruntuhkan nilai kolektifitas di perkotaan. Reaksi ini hadir sebagai upaya untuk menjaga tradisi dan mengukuhkan kembali nilai-nilai kolektifitas tersebut yang dikhawatirkan menghilang. 


\section{Fastabiq: Jurnal Studi Islam}

ISSN 2723-0228

Volume 1 Nomor 1 Juni 2020

Sebagai aktiftitas dakwah, kegiatan utamanya memang ceramah keagamaan yang kadang dilakukan juga pengkajian kitab tertentu. Materi-materi pengajian pada umumnya berkisar pada aspek fiqih, akhlaq dan tauhid. Cukup jarang ditemukan materi pengajian di majelis taklim perdesaan yang mengupas ketahanan keluarga dari aspek ekonomi. Padahal Islam memiliki pesan yang kuat bagi pemeluknya untuk memiliki kemandirian di bidang ekonomi. Pola pengajian yang dilakukan lebih menyantuni kebutuhan rohani, masih sedikit yang menjadikan momentum kebersamaan sebagai modal sosial untuk melahirkan gerakan ekonomi.

Dibandingkan dengan majlis taklim lainnya yang ada di Arjasari, Majlis Taklim al Falah memiliki citratersendiri. la bukan hanya menjadi wadah integratif pada dimensi relijiusitas belaka. la memainkan peran penting sebagai basis gerakan sosial ekonomi keagamaan bagi anggotanya. ${ }^{48} \mathrm{Di}$ Jawa Barat, majelis taklim telah memainkan peran tersendiri dalam kehidupan keberagamaan kaum ibu. Menurut Julian Mille, ${ }^{49}$ majelis taklim menjadi ruang publik tempat jamaah bertukar informasi, yang tidak hanya terbatas tentang informasi keagamaan saja. Majelis taklim dalam peran sosialnya ini memang menjadi berbeda dengan lembaga pengetahuan Islam lainnya. ${ }^{50}$ Pesantren misalnya, memiliki keterikatan yang khas dengan kiai atau ulama yang menjadi salahsatu pusat dari kekhasan pesantren itu sendiri. Sementara itu, seperti telaahan Mille, majelis taklim lebih cair dalam hal sumber informasi bagi jamaah. Seperti yang dapat disaksikan dalam aktifitas di majelis taklim yang lain, Majelis Taklim al Falah-pun memiliki tingkat likuiditas yang serupa dalam hal sumber informasi bagi jamaah. Ada beberapa orang yang menjadi pembina dan secara bergiliran mengisi kegiatan ceramah keagamaan di sana, termasuk unsur Penyuluh Agama dari KUA Arjasari.

Aktifitas pengajian di Majelis Taklim al Falah ini menggunakan ruangan masjid, Masjid Al Falah. Jadi, penamaan majelis taklim mengikuti nama masjid yang menjadi pusat kegiatan umat Islam di Arjasari khususnya warga RT 3 RW 6 Desa Arjasari. Posisi masjid ini sendiri berada di pertigaan jalan raya Arjasari dengan simpangan yang akan menuju ke area pertanian milik Unpad. Di seberang Masjid berdiri gedung Kantor Urusan Agama Arjasari. Keberadaan masjid ini dari aspek tersebut memiliki keuntungan tersendiri karena dekat dengan pihak pemerintahan yang berwenang dalam pembinaan keagamaan.

Hampir merupakan pemandangan umum di Jawa Barat bahwa keberadaan majelis taklim selalu berbagi ruangan dengan masjid. ${ }^{51}$ Meskipun ada juga yang memisahkannya bukan hanya dengan batas berupa gordyin atau partisi lainnya melainkan dipisahkan juga bangunannya dengan masjid. Untuk alasan-alasan tertentu, ada pendapat bahwa perempuan karena memiliki keterbatasan fisik seperti harus mengalami datang bulan, sementara ia tetap ingin megikuti kegiatan di majelis taklim, maka pemisahan ruangan antara ruang masjid dan majelis taklim untuk kaum ibu menjadi penting dilakukan. namun ada juga yang karena keterbatasan lahan atau berpendapat bahwa selama bisa dijaga kesucian masjid, maka pengajian tetap menggunakan ruangan yang sama di dalam masjid seperti halnya untuk kegiatan kaum lelaki.

Secara umum, kegiatan keagamaan di majlis taklim al falah pada dasarnya serupa dengan majlis taklim lain di Jawa Barat. Jamaahnya adalah kaum ibu dengan kondisi rata rata menikah dan usia di atas 30 tahunan. Kegiatan pengajian diawali dengan puji-pujian, shalawat kepada nabi dan 


\section{Fastabiq: Jurnal Studi Islam}

ISSN 2723-0228

Volume 1 Nomor 1 Juni 2020

bacaan ayat ayat al Quran. Setelah itu dilanjutkan dengan mendengarkan tausyiah dari ustadz yang menjadi pembina di majlis taklim. Kegiatan ini rutin dilaksanakan seminggu sekali setiap hari kamis mulai selepas dzuhur, tepatnya pukul 14.00 WIB. dan Para pembina MT al Falah menyadari betul kondisi sosial ekonomi jamaahnya yang terbatas mengingat sumber daya ekonomi hanya bertumpu pada sektor tani. Mereka yang terdiri atas unsur tokoh masyarakat (Apifudin, Kholisoh) dan unsur Penyuluh Agama ${ }^{52}$ selaku Pembina MT yang memberikan dorongan teologis bagi jamaahnya untuk melakukan sebuah gerakan. Aksi ini sangat penting ketika dalam situasi keterbatasan akses ekonomi, memberikan peluang pada beberapa pihak untuk hadir dalam perbantuan semu. Mereka yang menyasar ekonomi subsistensi perdesaan dengan kedok pinjaman lunak yang sejatinya adalah rentenir.

Menurut Mahbub, dorongan kuat bagi jamaah adalah salah satu ayat dalam Alquran yang cukup sering disampaikan sehingga tertanam kuat dalam diri jamaah adalah ${ }^{53}$ Q.S. Al Baqoroh ayat 26. Dorongan teologis ini tidak menjadikan mereka dalam keterbatasannya untuk tidak terlibat secara aktif dalam penggalangan dana. Melalui kencleng yang semula beredar saat pengajian kini telah melembaga menjadi sebuah wadah yang resmi dan menjadi salahsatu peluang untuk menuju kemandirian dalam ekonomi, terbebas dari jerat rentenir.

Pembacaan atas konteks sosial yang mengalami keterbatasan akses ekonomi pada jamaahnya, disertai spirit perubahan sesuai dengan semangat Wahyu, menemukan momentumnya ketika tahun 2001 Bupati Bandung kala itu memiliki program pemberdayaan ummat melalui pembentukan koperasi. ${ }^{54}$ Mengingat koperasi memiliki kelenturan dalam pembentukan dan pengelolaanya serta dinaungi oleh perubahan - perubahan lingkungan termasuk regulasi maka koperasi yang diinisiasi melalui majlis taklim al falah ini berbentuk koperasi syariah, dengan nama koperasi syariah al falah. Koperasi ini memiliki modal awal berupa dana stimulant dari Bupati Bandung sebesar Rp. 10.000.000,00 (Sepuluh Juta Rupiah). Perkembangan berikutnya ketika koperasi harus mendaftarkan diri agar berbadan hokum terjadi perubahan nama menjadi koperasi baitul maal wa tamwil Dana Akhirat. Sejak tahun 2002 telah diresmikan adanya Baitul Mal wa Tamwil Dana Akhirat sebagai wujud aksi dari teologi perubahan ${ }^{55}$.

Perubahan nama dari al falah menjadi Dana Akhirat meskipun berbeda redaksi namun menurut Supriadi tidaklah mengubah substansi. ${ }^{56}$ Nama al Falah memang diambil dari nama Majlis Taklim yang membidani lahirnya kelompok pengelola keuangan dalam bentuk koperasi ini. Al Falah juga bermakna ada doa di dalamnya yakni raihan kebahagiaan oleh anggota maupun muslim di Arjasari secara luas. Ketika ada perubahan menjadi Dana Akhirat, sejatinya tidak mengubah maksud doa ini sendiri. Karena menurutnya, Dana Akhirat juga bermakna bahwa setiap nilai rupiah yang terhimpun dalam BMT Dana Akhirat disertai harapan agar menjadi kencelng tabungan kebaikan yang dapat dipetik di akhirat kelak. Lebih jauh menurutnya, meskipun BMT tidak sepenuhnya bergerak dalam ruang nonprofit, sebab ada keuntungan yang ditarik dari perputaran uang oleh anggota, namun hendaknya jangan melupakan semangat awal yakni agar sama sama keluar dari permaslaahan ekonomi dan sama sama terangkat dalam derajat muslim yang berada dalam posisi tangan yang di atas, yakni pihak yang menolong. 


\section{Fastabiq: Jurnal Studi Islam}

ISSN 2723-0228

Volume 1 Nomor 1 Juni 2020

Jika dilihat dari persaingan dalam pengelolaan koperasi dengan waktu yang sama dan modal yang sama yaitu stimulan dari Bupati Bandung, maka salah satu kelebihan BMT Dana Akhirat yang mampu bertahan sampai sekarang adalah adanya motivasi religious ini. ${ }^{57}$ Sejak berdiri hingga kini, keanggotaan BMT Dana Akhirat telah melampaui jumlah jamaah di Majlis Taklim al Falah itu sendiri. Bermula menumpang di kantor RW kini telah memiliki asset tanah seluas $295 \mathrm{~m}^{2}$ dan total dana dikelola dari 894 anggota aktif mencapai 8.5 Milyar ${ }^{58}$. Akhirnya bukan hanya anggota atau jamaah Majlis Taklim al Falah saja yang merasakan keuntungan adanya BMT yang mereka kelola, melainkan juga masyarakat pada umumnya di sekitar Majlis Taklim al Falah-pun turut mendapat berkah ${ }^{59}$.

Islam dalam hal ini yang dapat digunakan untuk menjelaskan kehidupan muslim di Arjasari bukan hanya sebagai agama yang dianut dan berfungsi mengatur pola hubungan manusia dengan Tuhan semata, melainkan juga spirit berketuhanan ini mengejawantah dalam relasi sosialnya. ${ }^{60}$ Pemahaman ini berangkat dari kerangka Islam dalam dimensi kesejarahan. Lahirnya Islam adalah bukan hanya merubah tatanan spiritualistas masyarakat Arab Quraisy dewasa itu, melainkan juga merombak tatanan sosial yang ada dalam hegemoni ketidakadilan. Intinya Islam menjadi spirit perjuangan dalam upaya menuju keadilan sosial.

Islam yang telah menjadi identitas budaya dan sistem sosial di Arjasari semakin perlu untuk hadir dalam penyelesaian persoalan di Arjasari. Konstruksi Islam yang dikedepankan adalah pada tataran ekonomi. Mungkin memang masih banyak persoalan lain yang memerlukan jawaban, namun kebutuhan nyata saat ini yang dihadapi muslim perdesaan di Arjasari adalah pembiayaan yang membawa spirit Islam. BMT Dana Akhirat bukan hanya menjadi wadah kolektifitas bagi jamaah MT AI Falah dan sekitarnya termasuk muslim lainnya. BMT Dana Akhirat seperti namanya sendiri yang bernuanasa eskatologis menyiratkan bahwa kehidupan hari ini merupakan bagian dari kehidupan masa yang akan datang. Kata Akhirat menjadi semacam tausyiah tersendiri bagi anggota BMT untuk selalu mengedapankan pesan-pesan Islam dalam aktifitas keseharian.

Sebuah pernyataan yang penting dan seringkali diulang-ulang oleh pengurus BMT, dalam hal ini yaitu ketua BMT, bahwa penting bagi umat Islam untuk memerangi riba, terutama yang dilakukan rentenir. BMT Dana Akhirat menyebut mereka sebagai lintah darat yang harus dimusnahkan, seraya mengutip penggalan ayat al Quran surah al Baqarah ayat 276. Kesadaran inilah yang senantiasa menjadi framming bagi keberlangsungan gerakan sosial ekonomi di perdesaan melalui BMT Dana Akhirat. ${ }^{61}$

Keadilan, menjadi prinsip yang dipegang dalam gerakan melalui BMT Dana Akhirat. Keadilan dimaksud adalah siapapun warga berhak untuk dapat hidup layak dan memperjuangkan dirinya. Keterbatasan modal seringkalimenjadi penyebab dari sulitnya mereka keluar dari lingkaran persoalan ekonomi di perdesaan. Pemikiran serupa merupakan spirit yang mengilhami Yunus untuk turun tangan membantu kaum miskin melalui Grameen Bank. ${ }^{62}$ Perbedaan mendasar dengan BMT Dana Akhirat adalah pada pelayanan orang yang dapat meminjam atau menabung. BMT Dana Akhirat membatasi pada keanggotaan, sedangkan Grameen Bank terbuka sepapun dapat menjadi nasabah sesaui dengan prinsip perbankan. Titik temunya adalah pembelaan pada kaum marjinal yang oleh bank konvensional dianggap kurang layak untuk mendapatkan kredit. 


\section{Fastabiq: Jurnal Studi Islam}

ISSN 2723-0228

Volume 1 Nomor 1 Juni 2020

Islam menjadi gagasan, norma dan sistem nilai dalam gerakan. Gagasan merupakan suatu konstruksi pemikiran yang dibangun secara sosial di antara pengemban kebudayaan dalam menyikapi lingkungan dan alam sekitarnya. ${ }^{63}$ Gagasan tersebut, pada akhirnya berujung menjadi, berupa nilai, norma, pengetahuan dan teknologi. ${ }^{64}$ Nilai adalah gagasan mengenai apakah suatu pengalaman berarti, berharga, bernilai dan pantas atau tidak berarti, tidak berharga, tidak bernilai dan tidak pantas. ${ }^{65}$ Nilai, juga berkaitan dengan ide yang dimiliki secara bersama tentang sesuatu itu baik atau buruk, diharapkan atau tidak diharapkan. ${ }^{66}$ Nilai-nilai yang terdapat dalam masyarakat perdesaan banyak. Namun dari sekian banyak nilai, yang relevan dibahas di sini adalah kepercayaan, resiprositas, dan rasa tanggung jawab.

Bacaan atas wahyu (Alquran) sebagai landasan teologis menuju konstelasi praksis yang mampu menjawab pelbagai persoalan umat relevan dengan semangat tafsir transformatif yang diusung Abdurrahman ${ }^{67}$. Menurutnya Alquran, bukan hanya totalitas Tuhan semata, melainkan sebagai firman ia menjadi daerah tafsiran yang selalu terbuka dan dinamis mengikuti dinamika sosial umat manusia sebagai pihak yang menjadi subjek sekaligus objek atas petunjuk itu. Teologi pada ahirnya tidak selalu hanya dibaca secara skriptual melainkan memerlukan perangkat lain agar lebih membumi dan aplikatif sehingga benar-benar mampu membawa umat manusia pada titik puncak peradabannya yang berlandaskan etika tauhid.

Tafsir transformatif merupakan kegiatan pembacaan wahyu secara bersama-sama dalam suasana dialogis dalam rangka merumuskan praksis bersama. Proyek ini, menurut Abdurahman, merupakan politik opini yang berangkat dari wahyu (teologi) untuk memasilitasi keampuan umat mendefinisikan keadaan yang disebut 'adil' dan yang 'tidak adil' ${ }^{68}$. Perubahan dari ketidakadilan menuju keadaan yang adil bukan hanya berwacana dalam konteks bahasa, melainkan menjadi aksi nyata.

Aksi kaum ibu di al Falah boleh dikatakan merupakan wujud dari teologi perubahan, dari wahyu ke aksi. Bermula dari kesadaran relijius dan membaca atas kesadaran realitas untuk bersamasama mewujudkan sikap keberpihakan atas ketimpangan ekonomi sosial yang ada di lingkungannya merupakan refleksi dari tafsir transformatif ini. Kecil percikan api semangatnya namun dipelihara dengan aksi dan disemagati oleh dorongan wahyu bermuara kepada gerakan yang lebih besar, dari individu menuju kelompok, dari kelompok menuju jamaah.

Atas aksi tersebut, menunjukkan bahwa sejatinya muslim perdesaan Arjasari yang dalam kategori Woodward ${ }^{69}$ dan Kurzman $^{70}$ sebagai tipikal tradisionalis ternyata mampu menyatakan diri untuk melahirkan tindakan bersama dalam perilaku ekonomi melalui BMT sebagai wadah gerakan sosial. Sejauh riset di bidang ini, kesadaran dan tindakan ekonomi lebih sering ditemukan pada kelompok agama tipe modernis, baik dalam kristen maupun Islam. Weber dengan studi etika protestan, dan Geertz dengan aktifitas pedagang muslim yang berasal dari kaum santri dalam polarisasi keberislaman orang jawa. ${ }^{71}$

\section{SIMPULAN}




\section{Fastabiq: Jurnal Studi Islam}

ISSN 2723-0228

Volume 1 Nomor 1 Juni 2020

Teologi perubahan merupakan keniscayaan untuk menjadi spirit gerakan ketika bertemu dengan ruang sosial (konteks) yang tepat sebagai lahan implementasi aksi. Wahyu menjadi sebagai spirit teologis ketika dibaca dalam konteks sosial yang aktual ia menjadi landasan atas proyek perubahan yang mungkin dilakukan. Hadirnya gerakan sosial keagamaan berupa BMT Dana Akhirat di Majlis Taklim al Falah Arjasari menjadi salahsatu bentuk operasional dari dorongan teologis ke aksi nyata. Majlis Taklim memang berpeluang untuk mengembangkan peran dan fungsi sosialnya, bukan hanya dalam konteks wadah untuk menimba pengetahuan agama sebagai wujud relijiusitas jamaah. Sebagai sebuah refresentasi perkumpulan kaum ibu, di masa depan majlis taklim memiliki peluang lebih banyak dalam pemberdayaan keluarga muslim agar terlepas dari kondisi berkekurangan secara ekonomi.

\section{Ucapan Terima Kasih}

Penyusun mengucapkan terimakasih kepada para narsumber (Mahbub Basyari dan Samsu, Penyuluh Agama dan Pembina MT Al Falah; Aep Supriadi, pengelola BMT dan Pembina MT Al Falah) yang telah bersedia menjadi partisipan dalam penelitian ini. 


\section{ENDNOTES}

${ }^{1}$ Nugraha, Firman. 2013. "Penyuluhan Transformatif sebuah Model Dakwah." Jurnal Ilmu Dakwah (Fakultas Dakwah UIN Bandung) VII (21); lihat juga Rahman, Fazlur. 1985. "Approaches to Islam in Religious Studies: A Review Essay." In Approaches to Islam in Religious Studies, by Richard C. Martin. Tucson: The University Arizona Press.

${ }^{2}$ Nugraha, Firman. 2013. "Penyuluhan Transformatif sebuah Model Dakwah." Jurnal IImu Dakwah (Fakultas Dakwah) VII (21).

${ }^{3}$ Muslim Abdurahman. 1997. Islam Transformatif. Jakarta: Pustaka Firdaus.

${ }^{4}$ Harjani, Munzir Suparta dan Hefni. 2003. Metode Dakwah. Jakarta: Kencana.

5 (Q.S. Ali Imran (3): 110).

${ }^{6}$ Muhtadi, Asep Saeful. 2008. Komunikasi Politik Indonesia: Dinamika Politik Pasca Orde baru. Bandung: Rosdakarya.

${ }^{7}$ Ilaihi, M. Munir dan Wahyu. 2006:253. Manajemen Dakwah. Jakarta: Rahmat Semesta.

${ }^{8}$ Ilaihi, M. Munir dan Wahyu. 2006:258. Manajemen Dakwah. Jakarta: Rahmat Semesta.

9 Setiawan, Asep Iwan. 2009. "Dakwah dan Perubahan Sosial." Tatar Pasundan (Balai Diklat Keagamaan Bandung) III (3).

${ }^{10}$ Gerungan, W. 2004. Psikologi Sosial. Jakarta: Rineka Cipta.

11 Salahsatu spirit mengenai kesadaran kolektif ini, yang dapat diambil dari al Quran adalah sebagaimana termakub dalam Surat Ali Imran ayat 110. Lihat dalam Firman Nugraha, 'Penyuluhan Agama Transformatif Sebuah Model Dakwah'. Jurnal IImu Dakwah. Bandung: FDK UIN Bandung

${ }^{12}$ M. Luthfi Malik, Etos Kerja, Pasar dan Masjid: Transformasi Sosial Keagamaan dalam Mobilitas Ekonomi Kemasyarakatan (Jakarta: LP3ES, 2013).

${ }^{13}$ Helmawati, Pendidikan Nasional dan Optimalisasi Majelis Taklim (Jakarta: Rineka Cipta, 2013), 76 78.; Agus Ahmad Safei (2016) [b]. 'Development of Islamic Society Based on Majelis Ta'lim: A Study of the Shifting Role of the Majelis Ta'lim in West Java'. American Journal of Applied Sciences. 2016, 13 (9): 947.952

${ }^{14}$ Bimas Islam Kementerian Agama mencatat bahwa pada tahun 2013 (dengan jumlah data yang masuk dari 33 propinsi) terdapat 158.960 yang terdaptar dengan jumlah jamaah 4.173.870. Sementara itu masih dari sumber yang sama, Jawa Barat memiliki 39.357 majelis taklim dengan 390.221 jamaah binaan. Jumlah ini di luar Majelis Taklim yang belum terdaftar atau mendaftarkan diri. Hal ini berdasarkan pengetahuan peneliti bahwa ditempat tinggal peneliti sendiri ada majelis taklim dengan aktifitas rutin namun tidak terdaftar atau belum mendaftarkan diri kepada Kementerian Agama. Jumlah angka tersebut jelas mengalami pertumbuhan signifikan jika dibandingkan dengan tahun 2011 (dengan jumlah data yang masuk dari 31 Propinsi). Pada tahun 2011 secara nasional Majelis Taklim terdaftar ada 98.260. Sementara Di Jawa Barat pada tahun yang sama ada 8.192 majelis taklim. Untuk lebih jelasnya dapat dilihat di http://simbi.kemenag.go.id/data-bida. Diakses 14 Nopember 2016.

${ }^{15}$ Rosehan Anwar (ed.), Majelis Taklim dan Pembinaan Umat (Jakarta: Puslitbang Lektur Keagamaan, 2004), ix; Kustini (ed.), Peningkatan Peran Serta Masyarakat dalam Pendalaman Ajaran Agama melalui Majelis Taklim (Jakarta: Puslitbang Kehidupan Keagamaan, 2007), 18-21;

16 Amri Almi, Pengembangan Masyarakat melalui Majelis Taklim, Thesis Institut Pertanian Bogor, 2010 (Tidak dipublikasikan); Nugraha, Firman. 2018. "Majlis Taklim sebagai Basis Pemberdayaan Umat." Tatar Pasundan (Balai Diklat Keagamaan Bandung) XII (33): 12-21.

17 Julian Millie, 'Islamic Preaching and Women's Spectatorship in West Java'. The Australian Journal of Anthropology (2011) 22, 151-169.

${ }^{18}$ Firman Nugraha, 'the Role of majelis Taklim in Social Dynamics of Muslims, Jurnal Bimas Islam Vol. 9. No. 3, 2016.

${ }^{19}$ Agus Ahmad Safei, (2016) [a]. 'The Development of Islamic Society Based on Celestial Business' Walisongo: Jurnal Penelitian Sosial Keagamaan, Vol. 24 No. 1, Mei 2016. 
${ }^{20}$ Firman Nugraha, 'the Role of majelis Taklim in Social Dynamics of Muslims, Jurnal Bimas Islam Vol. 9. No. 3, 2016.

${ }^{21}$ Saleh, Fauzan. 2004. Teologi Pembaruan: Pergeseran Wacana Islam Sunni di Indonesia Abad XX. Jakarta: Serambi.

${ }^{22}$ Quthb, Sayyid. 2003. Tafsir Fi Zhilalil Quran. Vol. II. Jakarta: Gema Insani Press.

${ }^{23}$ Quthb, Sayyid. 2003. Tafsir Fi Zhilalil Quran. Vol. II. Jakarta: Gema Insani Press.

${ }^{24}$ Nugraha, Firman. 2013. "Penyuluhan Transformatif sebuah Model Dakwah." Jurnal Ilmu Dakwah (Fakultas Dakwah); Engineer, Ashgar Ali. 2000. Devolusi Negara Islam. Yogyakarta: Lkis.

${ }^{25}$ Hilmy, Masdar. 2008. Islam Profetik: Substansi Nilai-nilai Agama di Ruang Publik. Yogyakarta: Kanisius.

${ }^{26}$ QS Al-Fath (48):13.

${ }^{27}$ QS Al-Hasyr (59):17

${ }^{28}$ QS Al-Baqarah (2):219

${ }^{29}$ QS Al-Qasas (28):5

${ }^{30}$ QS Al-Baqarah (2):256

${ }^{31}$ QS Al-Kafirun (109):6

${ }^{32}$ QS An-Nisa (4):150-151

${ }^{33}$ Abdurahman, Muslim. 2003. Islam Sebagai Kritik Sosial. Jakarta: Erlangga.

${ }^{34}$ Zada, Khamami. 2006. Dakwah Transformatif: mengantar da'i sebagai pendamping Masyarakat. Lakpesdam NU.

${ }^{35}$ Badan Pusat Statistik Kabupaten Bandung, Statistik Daerah Kecamatan Arjasari 2016 (Bandung: BPS Kab. Bandung, 2017), 1

${ }^{36}$ Badan Pusat Statistik Kabupaten Bandung, Statistik Daerah ..., 1

${ }^{37}$ Badan Pusat Statistik Kab. Bandung, Kecamatan Arjasari dalam Angka 2016..., 4-7

${ }^{38}$ Badan Pusat Statistik Kabupaten Bandung, Statistik Daerah Kecamatan Arjasari 2016 (Bandung: BPS Kab. Bandung, 2017), 81-82.

39 Firman Nugraha, Agama dan Gerakan Sosial Ekonomi Muslim Perdesaan (Bandung: Pasca Sarjana Uln Bandung, 2018)., 141.

40 Badan Pusat Statistik Kab. Bandung, Kecamatan Arjasari dalam Angka 2016..., 23,24.; Badan Pusat Statistik Kab. Bandung, Kecamatan Arjasari dalam Angka 2016..., 26-28

${ }^{41}$ Aep Supriadi, wawancara (18 Februari 2018)

42 Firman Nugraha, Agama dan Gerakan Sosial Ekonomi Muslim Perdesaan (Bandung: Pasca Sarjana UIn Bandung, 2018)., 149-153; 162-164.

${ }^{43}$ Badan Pusat Statistik Kab. Bandung, Kecamatan Arjasari dalam Angka 2016..., 60

${ }^{44}$ Mahbub Basyari, wawancara (18 Februari 2018)

${ }^{45}$ Tutty Alawaiyah, Strategi Dakwah di Lingkungan Majelis Taklim..., 75.

46 Helmawati menguraikan cukup panjang pemaknaan ta'lim dan mu'allim, Lihat Helmawati, Pendidikan Nasional dan Optimalisasi Majelis Taklim..., 78-86

${ }^{47}$ Lihat dalam Rosehan Anwar (ed.), Majelis Taklim dan Pembinaan Umat (Jakarta: Puslitbang Lektur Keagamaan, 2004), viii-ix.

${ }^{48}$ Firman Nugraha, 'Gerakan Ekonomi Keagamaan dan Politik Identitas Muslim Perdesaan' Jurnal Bimas Islam Vo. 11 No. 4 Tahun 2018. (Jakarta: Bimas Islam, 2018), 702-705.

${ }^{49}$ Julian Millie, 'Islamic Preaching and Women's Spectatorship in West Java'. The Australian Journal of Anthropology (2011) 22, 151-169.

${ }^{50}$ Helmawati memandang majelis taklim sebagai lembaga pendidikan bagi jamaahnya, berarti majelis taklim dalam fungsinya ini dapat dianggap sama dengan keberadaan lembaga pendidikan lainnya seperti pesantren. Helmawati, Pendidikan Nasional dan Optimalisasi Majelis Taklim (Jakarta: Rineka Cipta, 2013), 76-78

${ }^{51}$ Keberadaan majelis taklim dapat diselenggarakan tidak selalu di masjid, mungkin di madrasah, mungkin juga di rumah jamaah secara bergilir. Lihat dalam Lihat Tutty Alawaiyah, Strategi Dakwah di Lingkungan Majelis Taklim..., 77.

52 Basyari, Mahbub dan Samsu, interview by Firman Nugraha. 2017. Posisi tokoh agama dalam pembinaan umat (Nopember 7).

${ }^{53}$ QS Al-Baqarah 26; Basyari, Mahbub dan Samsu, interview by Firman Nugraha. 2017. Posisi tokoh agama dalam pembinaan umat (Nopember 7).

${ }^{54}$ Aep Supriadi, wawancara, 18 Februari 2018.

${ }^{55}$ Supriadi, Aep, interview by Firman Nugraha. 2018. Sejarah BMT Dana Akhirat (Februari 18). 
${ }^{56}$ Aep Supriadi, wawancara, 18 Februari 2018.

${ }^{57}$ Weber, menemukan spirit reformis dalam protestan yang mendorong pemeluknya untuk bersikap terbuka terhadap kemajuan, sesuatu yang tidak ia temukan dalam iman Katolik yang menjadi antitesa iman Protestan. Lihat dalam Max Weber, Etika Protestan dan Semangat Kapitalisme (Jakarta: Serambi, 2000); Rodney Stark and Roger Pinke, Acts of Faith (California: University of California Press, 2000); lihat juga dalam Roger Finke and Rodney Stark, 'The Dynamics of Religious Economies', dalam Michele Dillon (ed), Handbook of Sociology of Religion (New York: Cambridge University Press, 2003), 96-109

${ }^{58}$ Nugraha, Firman. 2018. "Majlis Taklim sebagai Basis Pemberdayaan Umat." Tatar Pasundan (Balai Diklat Keagamaan Bandung) XII (33): 12-21

59 Basyari, Mahbub dan Samsu, interview by Firman Nugraha. 2017. Posisi tokoh agama dalam pembinaan umat (Nopember 7).

${ }^{60}$ Kuntowijoyo, Paradigma Islam Interpretasi untuk Aksi (Bandung: Mizan, 1991).

61 Bellah menemukan sikap serupa dalam hubungan kesalehan dengan etos penduduk Jepang. Robert N. Bellah, Religi Tokugawa Akar-akar Budaya Jepang (Jakarta: Gramedia, 1992), 166.

${ }^{62}$ Muhammad Yunus, Bank Kaum Miskin (Jakarta: Marjin Kiri, 2007)

${ }^{63}$ Pengertian ini senada dengan pemahaman kebudayaan. Lihat dalam Koentjoroningrat, Pengantar IImu Antropologi..., 180.

${ }^{64}$ Ini adalah apa yang disebut dengan tiga wujud kebudayaan. Koentjoroningrat, Pengantar IImu Antropologi..., 186-187.

65 Paul B. Horton and Chester L. Hunt, Sociology ..., 63.

${ }^{66}$ Koentjoroningrat, Pengantar Ilmu Antropologi..., 190.

${ }^{67}$ Abdurahman, Muslim. 2003. Islam Sebagai Kritik Sosial. Jakarta: Erlangga.

${ }^{68}$ Abdurahman, Muslim. 2003. Islam Sebagai Kritik Sosial. Jakarta: Erlangga.

${ }^{69}$ Mark Woodward, Islam Jawa Kesalehan Normatif versus Kebatinan (Yogyakarta, LKiS, 2008).

${ }_{71}^{70}$ Charles Kurzman, Liberal Islam a Source Book (New York: Oxford University Press, 1998).

71 Lihat dalam Max Weber, Etika Protestan dan Semangat Kapitalisme (Jakarta: Serambi, 2000); Clifford Geertz, Peddlers and Princes: Social Change and Economic Modernaization in Two Indonesian Towns, (Chicago: The University of Chcago, 1963). 


\section{REFERENSI}

Abdurahman, Muslim. 2003. Islam Sebagai Kritik Sosial. Jakarta: Erlangga. 1997. Islam Transpormatif. Jakarta: Pustaka Firdaus.

Agus Ahmad Safei, 'The Development of Islamic Society Based On Celestial Business' Walisongo: Jurnal Penelitian Sosial Keagamaan, Vol. 24 No. 1, Mei 2016, 1-16.

Agus Ahmad Safei, 2016, [b]. 'Development of Islamic Society Based on Majelis Ta'lim: A Study of the Shifting Role of the Majelis Ta'lim in West Java'.American Journal of Applied Sciences. 2016, 13 (9): 947.952

Amri Almi, Pengembangan Masyarakat melalui Majelis Taklim, Thesis Institut Pertanian Bogor, 2010 (Tidak dipublikasikan);

Basyari, Mahbub dan Samsu, Interview by Firman Nugraha. 2017. "Posisi Tokoh agama dalam pembinaan umat," (Nopember 2017).

Badan Pusat Statistik. 2017. Kabupaten Bandung dalam Angka 2016. Bandung: Badan Pusat Statistik.

Badan Pusat Statistik Kabupaten Bandung, 2017, Statistik Daerah Kecamatan Arjasari 2016, Bandung: BPS Kab. Bandung.

Charles Kurzman, 1998, Liberal Islam a Source Book, New York: Oxford University Press.

Clifford Geertz, 1963, Peddlers and Princes: Social Change and Economic Modernaization in Two Indonesian Towns, Chicago: The University of Chcago.

Engineer, Asghar Ali. 2000. Devolusi Negara Islam. Yogyakarta: LKIS.

Gerungan, W. 2004. Psikologi Sosial. Jakarta: Rineka Cipta.

Harjani, Munzir Suparta dan Hefni. 2003. Metode Dakwah. Jakarta: Kencana.

Helmawati, 2013, Pendidikan Nasional dan Optimalisasi Majelis Taklim, Jakarta: Rineka Cipta.

Hilmy, Masdar.2008. Islam Profetik: Substansi Nilai-Nilai Agama di Ruang Publik. Yogyakarta: Kanisius.

http://simbi.kemenag.go.id/data-bida. Diakses 14 Nopember 2016.

Ilaihi, M. Munir dan Wahyu. 2006. Manajemen Dakwah, Jakarta: Rahmat Semesta.

Julian Millie, 2011, 'Islamic Preaching and Women's Spectatorship in West Java'. The Australian Journal of Anthropology (2011)

Koentjoroningrat, 2000. Pengantar IImu Antropologi. Jakarta: Rajawali Press.

Kuntowijoyo, 1991, Paradigma Islam Interpretasi untuk Aksi, Bandung: Mizan.

Kustini (ed.), 2007, Peningkatan Peran Serta Masyarakat dalam Pendalaman Ajaran Agama melalui Majelis Taklim (Jakarta: Puslitbang Kehidupan Keagamaan.

Mark Woodward, 2008, Islam Jawa Kesalehan Normatif versus Kebatinan, Yogyakarta, LKiS.

Max Weber, 2000, Etika Protestan dan Semangat Kapitalisme, Jakarta: Serambi.

M. Luthfi Malik, 2013, Etos Kerja, Pasar dan Masjid: Transformasi Sosial Keagamaan dalam Mobilitas Ekonomi Kemasyarakatan, Jakarta: LP3ES. 
Fastabiq: Jurnal Studi Islam

ISSN 2723-0228

Volume 1 Nomor 1 Juni 2020

Muhtadi, Asep Saeful. 2008. Komunikasi Politik Indonesia: Dinamika Politik Orde Baru. Bandung: Rosdakarya.

Muhammad Yunus, 2007, Bank Kaum Miskin, Jakarta: Marjin Kiri.

Nugraha, Firman. 2011, "Agama dan Perubahan Sosial," Jurnal Tatar Pasundan (Balai Diklat Keagamaan Bandung) IX (33):12-21.

Nugraha, Firman. 2013," Penyuluhan Transformatif sebuah Model Dakwah," Jurnal Ilmu Dakwah (Fakultas Dakwah UIN Bandung) VII (21).

Nugraha, Firman, 2016, 'the Role of majelis Taklim in Social Dynamics of Muslims, Jurnal Bimas Islam Vol. 9. No. 3, 2016.

Nugraha, Firman. 2018. "Agama dan Gerakan Sosial Ekonomi Muslim Perdesaan.” Bandung: Pasca Sarjana UIN Bandung.

Nugraha, Firman. 2018. "Majlis Taklim sebagai Basis Pemberdayaan Umat." Jurnal Tatar Pasundan (Balai Diklat Keagamaan Bandung) XII (33):12-21.

Paul B. Horton and Chester L. Hunt, 1984. Sociology. MacGrawHills.

Quthb, Sayyid. 2003. Tafsir Fi Zhilalil Quran. Vol. II. Jakarta: Gema Insani Press.

Rahman, Fazlur. 1985." Approaches to Islam in Religious Studies: A Review Essay." In Approaches to Islam in Religious Studies by Richard C. Martin. Tucson: The University Arizona Press.

Robert N. Bellah, 1992, Religi Tokugawa Akar-akar Budaya Jepang, Jakarta: Gramedia.

Rodney Stark and Roger Pinke, 2000, Acts of Faith, California: University of California Press.

Roger Finke and Rodney Stark, 'The Dynamics of Religious Economies', dalam Michele Dillon (ed), Handbook of Sociology of Religion (New York: Cambridge University Press, 2003), 96-109

Rosehan Anwar (ed.), 2004, Majelis Taklim dan Pembinaan Umat, Jakarta: Puslitbang Lektur Keagamaan.

Saleh, Fauzan. 2004. Teologi Pembaruan: Pergeseran Wacana Islam Sunni di Indonesia Abad XX. Jakarta: Serambi.

Setiawan, Asep Iwan. 2009," Dakwah dan Perubahan Sosial," dalam Jurnal Tatar Pasundan (Balai Diklat Keagamaan Bandung) III (3).

Supriadi, Aep, interview by Firman Nugraha. 2018. "Sejarah BMT Dana Akhirat” “(Februari 2018).

Tutty Alawiyah, 1997. Strategi Dakwah di Lingkungan Majelis Taklim. Bandung: Mizan.

Zada, Khamami. 2006. "Dakwah Transformatif: Mengantar Da'i sebagai Pendamping Masyarakat." Lakpesdam NU. 